\title{
FORUM
}

\section{Integrated Pest Management (IPM) and Internet-Based Information Delivery Systems}

\author{
Waheed I. Bajwa ${ }^{1}$, Leonard Coop ${ }^{2}$ and Marcos Kogan ${ }^{2}$ \\ ${ }^{1}$ New York Department of Health, New York, NY 10007, USA \\ ${ }_{2}^{2}$ Integrated Plant Protection Center (IPPC), Oregon State University, Corvallis, OR 97331, USA
}

Neotropical Entomology 32(3):373-383 (2003)

Manejo Integrado de Pragas (MIP) e Sistemas de Liberação de Informação Sediados na Internet

RESUMO - A internet permite compartilhar a colaboração e a informação numa escala sem precedentes. Ela tornou-se um meio inédito para a comunicação em pesquisa e extensão. A rede mundial de computadores (World Wide Web - WWW) torna possível a combinação da informação de diferentes sites de uma maneira contínua. O potencial de uso da rede para integrar todo o tipo de informação, estática ou dinâmica, é unico e inédito. A rede permite fazer a interface para todos os tipos de base de dados interativos e para muitos tipos de análises e processamentos de dados on line. Modelos sediados na rede e sistemas para o apoio de decisões (decision support systems - DSS) estão se tornando populares porque poucos ou nenhum programa de sofware é necessário, dessa forma reduzindo o custo de distribuição e manejo de modelos. Nenhum outro meio oferece tais habilidades, como por exemplo, as informações climáticas em tempo quase real, multimidia, processos analíticos, discussão em vias múltiplas e feedback. O manejo integrado de pragas (MIP) é um sistema intensivo em informação. Ambos, a pesquisa em MIP e a sua implementação, requerem o suprimento de informação em tempo útil. A internet fornece meios para estabelecer a comunicação entre os pesquisadores em MIP e os profissionais da extensão e sua clientela, para maximizar a troca de informações e a transferência de tecnologias. A rede WWW abriu uma amplitude de fontes de dados para pesquisa, extensão, ensino e aprendizado em MIP, não concebida antes do advento da internet. O futuro do uso do MIP pela internet é promissor. A troca de informações baseada na internet está rapidamente se tornando um requisito indispensável para implementação de sistemas de MIP locais, regionais ou em áreas abrangentes e em nível internacional.

PALAVRAS-CHAVE: Internet, MIP, informática, sistema para apoio de decisões, sistema de computadores, sistema de alerta de pragas

ABSTRACT - The Internet enables collaboration and information sharing on an unprecedented scale. It has become a prime medium for research and extension communication. The World Wide Web (WWW) makes it possible to combine information from many different sites in a seamless fashion. The potential for using the web to integrate all types of static and interactive (dynamic) information is unique and unprecedented. The web provides excellent interfaces for all kinds of interactive network databases, and many kinds of online analyses and data processing. Web-based models and decision support systems (DSS) are becoming popular because little or no client software is required, thus reducing software management and distribution costs. No other medium offers such ability as simultaneous real-time weather information, multimedia, analytical processing and multi-way discussion and feedback. IPM is an information-intensive system. Both IPM research and implementation require the reliable supply of timely information. The Internet provides the means to establish communication links between IPM researchers and extension professionals and their clientele to expedite multi-way exchange of information and technology transfer. The Internet particularly the WWW, has opened up a rich array of data resources for IPM research, extension, teaching, and learning that was not as readily accessible before the advent of the Internet. The future of IPM delivery systems through the Internet is promising; internet-based information exchange is quickly becoming an absolute requirement for local, regional/areawide, and international implementation of IPM systems.

KEY WORDS: Internet, IPM, informatics, decision support system, computer system, pest alert system 
Over the past few years, the Internet has become a powerful medium for fast, worldwide dissemination of upto-date information. Its instant nature and global domain provide quick access to vast amounts of information. In fact, access to information is the essence of the Internet (Bajwa and Kogan 2000a). The Internet is not just a transmitter of information, it is also a means for exchange of information and can be used for storing, sorting, and analyzing information. Internet access is becoming ubiquitous, and as bandwidth improves, increasingly sophisticated graphics, audio, video, and animation elements can be included in the internet-based information systems. The internet is expanding at a remarkable rate (Fig. 1). Combining with other technologies (wireless data transmission, television, telephone, etc.), the Internet's ability to host multimedia information (text, graphic, video, audio) provides grounds for developing an integrated information supercommunication highway for all people, regardless of economic advantage, disability or geographical location.

Knowledge and information are key to correct pest management decisions. integrated pest management (IPM), a system that emphasizes appropriate decision making, is information intensive and depends heavily on accurate and timely information for field implementation by practitioners. Additionally, it is critical to strengthen the communication links between researchers and extension professionals and their clientele to expedite multi-way exchange of information and technology transfer. In addition, researchers and extension specialists need the most up-to-date information to design new projects and set future research goals and directions.

There is already a large volume of useful IPM information available on the Internet, however, the information is scattered all across the globe. These resources range from topics such as pest identification, biology, control tactics, IPM definitions and basic concepts, to modeling and systems analysis. As awareness of the Internet increases worldwide, more people are participating not only as users of the information but also as creators of new information; as a consequence, the number of both IPM Internet servers and clients is increasing rapidly, perhaps slightly lagging but generally accompanying the exponential growth of the internet itself (Fig. 1).

\section{The Internet as an Information Delivery and Exchange Tool}

An efficient information system requires rapid and accurate transmission of information at a minimal cost. Currently, different scientific communication media are being used such as printed materials, electronic archives on CDROM, and websites on the Internet. Among various Internet tools, the World Wide Web (Web) is the most rapidly growing medium for information exchange throughout the world. The web provides a cost-effective, multimedia means of delivering and exchanging quantitative and qualitative information via its user-friendly interactive interface. It makes information accessible globally to any person at any time.

The web provides a collaborative environment for the development and maintenance of electronic information that can occur among distant and dispersed developers and institutions (Gilman \& Green 1998). Since personal computers can be used and the browser software is low cost or free, the only requisite is an Internet connection. In academia and most research communities, the Internet connections are provided at no or low cost, and in the private sector Internet server providers (ISP) are reducing access charges to build up their clientele.

The web is advancing quickly toward mass-media status in the world. The current worldwide usage of internet is given in the Table 1. Internet has sustained double- and triple-digit annual growth (of servers) in the USA and throughout the world (Fig. 1). Having started with a small number of users with less than $1 \%$ of the USA population and less than $0.1 \%$ of the world population in 1990 (Gardner 1999), the web currently has approximately $606 \mathrm{M}$ users around the world (Table 1). In the USA, $58.2 \%$ of the

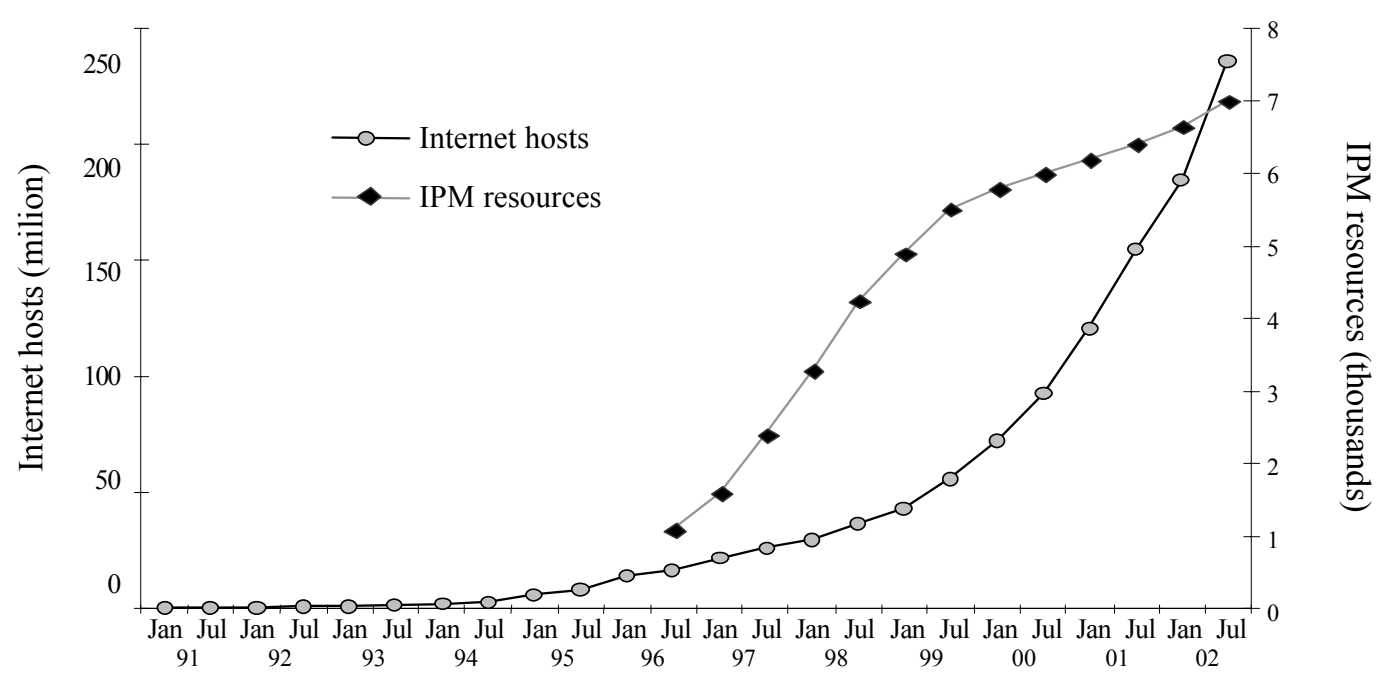

Figure 1. Number of Internet host from 1991 - 2002 (Network Wizards 2002- http://www.nw.com/) and IPM resources available through DIR, the database of IPM Resources (http://IPMnet.org/DIR). 
Table 1. Worldwide internet usage (September 2002).

\begin{tabular}{lc}
\hline Region & \multicolumn{1}{c}{ Users } \\
\hline World total & 605.60 million \\
Africa & 6.31 million \\
Asia/Pacific & 187.24 million \\
Europe & 190.91 million \\
Middle East & 5.12 million \\
Canada \& USA & 182.67 million \\
Latin America & 33.35 million \\
\hline
\end{tabular}

Source: NUA Surveys 2002

population used the Internet in December 2002, and the number is expected to grow to $70 \%$ in 2003 and $80 \%$ in 2005 (NUA Surveys 2002). The web may soon become a primary medium for exchange of scientific information replacing hardcopy books and serials. The libraries of the future will serve as electronic repositories of information (Lineberger 1998).

\section{Web-Based Interactive Systems}

The ability of web-based applications to access and query databases is a key to interactive applications on the Internet. Web databases may contain any type of data including extended text fields and binary objects such as graphics, sound, and video. These databases are generally used to manage dynamic information/data. Web databases can be used for information/data collection, distribution, or data exchange. Some of the uses of web databases include records of pest phenology, occurrence and distribution, pest control recommendations or pesticide information.

At present, most online IPM information is static (based on text and graphics only), such as electronic versions of informational brochures, pesticide recommendations, fact sheets, extension guides, and bibliographic references. These resources, however, offer several advantages over printed versions. Electronic dissemination of information, obviously, saves paper and eliminates the added expense of the physical distribution of printed copies. Electronic resources open the option to search and index text, and quick access to reference materials, as well as hyperlinking to other relevant resources. The number of online dynamic and interactive IPM resources, however, also is growing. Such systems facilitate a user's access to the decision making process. The dynamic online IPM tools include databases, degree-day and sampling calculators, and phenology/population dynamics models (Table 2). These interactive tools require end-users to respond to and share information online. Generally, these tools work efficiently if they are integrated with other online resources. Interactive tools such as email list servers, newsgroup, and WWW-based conferencing systems are used to add interactivity to websites. Several IPM lists in the form of digests, electronic journals, and discussion groups are now available.

Combined with flexible access to local and remote databases, the potential of the web far exceeds that of an information distribution channel. A well built online interactive system is Extension Digital Information Source (EDIS) (http://edis.ifas.ufl.edu/), an extension information exchange system developed by the University of Florida Cooperative Extension. Other examples include the ARS Pesticide Properties Database (http://www.arsusda.gov/rsml/ ppdb.html), and Virus databases on-line (http:// life.anu.edu.au/viruses/welcome.html).

\section{Online Analytical Processing (OLAP)}

The Internet also is becoming a preferred means of providing data and analytical processing for decision making via OLAP applications. Now it is possible to run multisource, integrated, multimedia, multi-threaded, site-specific automatic decision support systems on the Internet (Power \& Kaparthi 1998). Such systems facilitate a user's access to the decision making process (Eastwood 1998). Dynamic sites that include interactive models, Geographical Information System based decision systems, real-time weather, and market information are being rapidly developed and made available on the Internet. An example is the Pacific Northwest IPM Weather Data and DegreeDays Website (Coop 2000). At this site, daily temperature and precipitation data are gathered from 380 publicly and privately available weather stations and linked directly to pest phenology models for 22 insects, two diseases, two weed and two crop species. This system typically serves phenology updates and forecast to extension specialists who interpret and report the information for local needs. Another example is the plant production information system Pl@nteInfo (http://www.PlanteInfo.dk/login.asp) developed in 1996 by the Danish Agricultural Research and Advisory Organizations. A key feature of this system is pest and disease warnings based on weather data-driven forecast models. The meteorological data are transferred daily from the Danish Meteorological Institute to provide freshly updated warnings and recommendations (Thysen 1998). In 1997, Vandregnskab, a PC (personal computer)-based irrigation decision support system, was converted to an interactive Internet version and added to P1@nteInfo. This online version of Vandregnskab attracted more farmers in one year than the PC program had in five years, because of the automatic access to weather data and a more userfriendly layout (Thysen 1998).

\section{The Internet as a Multiway Information Exchange System}

The Internet is being increasingly used for multiway information exchange (including feedback). Email is typically used to send short textual messages between computer users. Clientele can access designated specialists/ experts via email. Internet News Groups permit users to read and post messages to various discussion groups organized by topic. News group postings (traffic) are very much like email messages, but are grouped by topic for a given subject (thread). The Internet provides thousands of discussion groups via email by allowing users to place themselves on electronic mailing lists. These mailing lists 
Table 2. Some outstanding online integrated pest management (IPM) resources from different regions and perspectives.

\author{
Information retrieval and referral systems \\ Database of IPM Resources (DIR) \\ http://www.IPMnet.org/DIR/ \\ Acarology WWW Home Page \\ http://www.nhm.ac.uk/hosted_sites/acarology/ \\ AgNIC- a guide to online agricultural information \\ http://www.agnic.org/ \\ Agricultural Genome Information Server \\ http://ars-genome.cornell.edu/ \\ All the Virology on the WWW \\ http://www.tulane.edu/ dmsander/garryfavweb.html \\ Arachnology Page (Spiders and their relatives) \\ http://www.ufsia.ac.be/Arachnology/Arachnology.html \\ Compendium of IPM Definitions (CID) \\ http://www.ippc.orst.edu/IPMdefinitions/home.html \\ Entomology Index of Internet Resources \\ http://www.ent.iastate.edu/list/ \\ Internet Resources on Weeds \& Their Control \\ http://www.ippc.orst.edu/cicp/gateway/weed.htm \\ Internet Resources on Vertebrate Pests \\ http://www.ippc.orst.edu/cicp/pests/vertpest.htm \\ IPMnet NEWS \\ http://ipmwww.ncsu.edu/cicp/IPMnet_NEWS/archives.html \\ Nematology Sites on the Web \\ http://nematode.unl.edu/wormsite.htm \\ Pesticide \& Agrichemical Industry Information \\ http://www.bmckay.com/ \\ Pesticide Information Profiles (PIPs) \\ http://ace.ace.orst.edu/info/extoxnet/pips/pips.html \\ Plant Pathology Internet Guide Book \\ http://www.ifgb.uni-hannover.de/extern/ppigb/ppigb.htm \\ US National Pesticide Information Retrieval System \\ http://www.ceris.purdue.edu/npirs/npirs.html
}

Phenology, models, and pest forecasting and alert systems (dynamic and integrated tools)

Blue Mold Forecast Website (USA)

http://www.ces.ncsu.edu/depts/pp/bluemold/

Disease Model Database (USA)

http://www.ipm.ucdavis.edu/DISEASE/DATABASE/

Models of Plants, Pests, and Beneficials

Using Degree-Days (USA)

http://www.ipm.ucdavis.edu/PHENOLOGY/models.html

Near Real-time Pest Alert Systems

http://ippc.orst.edu/pestalert/

Online Weather Data and Degree-Days (USA)

http://www.orst.edu/Dept/IPPC/wea/

\section{North America}

Biocontrol of Plant Diseases

http://www.barc.usda.gov/psi/bpdl/bpdl.html

BT (Bacillus thuringiensis) Toxin Resources

http://www.nalusda.gov/bic/BTTOX/bttoxin.htm

Cornell University's Guide to Natural Enemies in North America

http://www.nysaes.cornell.edu/ent/biocontrol/

Clemson Entomology - Insect Information http://entweb.clemson.edu/cuentres/

Crop Protection Guide (Insects, Disease, \& Weeds)

http://www.agr.gov.sk.ca/Docs/crops/cropguide00.asp

Diagnostic Key to Major Tree Fruit Diseases

in the Mid-Atlantic Region

http://www.caf.wvu.edu/kearneysville/wvufarm6.html

Electronic Resources on Lepidoptera

http://www.chebucto.ns.ca/Environment/NHR/lepidoptera.html

Fungal Databases

http://nt.ars-grin.gov/fungaldatabases/databaseframe.cfm

Northwest Berry \& Grape InfoNet

http://www.orst.edu/dept/infonet/

Overview of Organic Fruit Production

http://www.attra.org/attra-pub/fruitover.html

Pest/Biocontrol Information

http://www.ceris.purdue.edu/napis/pests/index.html

Pesticide Handling and Storage Tutorial

http://danpatch.ecn.purdue.edu/ epados/farmstead/pest/src/

main.htm

Photo Gallery of Insects and Mites

http://ipmwww.ncsu.edu/current_ipm/otimages.html

Plant and Insect Parasitic Nematodes Homepage

http://nematode.unl.edu/wormhome.htm

University of California Pest Management Guidelines

http://www.ipm.ucdavis.edu/

Urban Integrated Pest Management

http://hammock.ifas.ufl.edu/en/en.html

Weed Images and Descriptions

http://www.rce.rutgers.edu/weeddocuments/index.htm

\author{
Australasia \\ Insect and Allied Pests of Extensive Farming in Western \\ Australia \\ http://www.agric.wa.gov.au/ento/allied1.htm \\ Plant Viruses Online \\ http://biology.anu.edu.au/Groups/MES/vide/refs.htm
}

\section{Asia}

Japan's Pesticide Database

http://chrom.tutms.tut.ac.jp/JINNO/PESDATA/00database.html

Malaysia's Crop Technology

http://agrolink.moa.my/doa/english/croptech/crop.html

\section{Africa}

Biological control of Cereal Stemborers in East and Southern Africa

http://nbo.icipe.org/agriculture/stemborers/default.html

\section{South America}

Brazilian National Fungal Catalogue

http://www.bdt.org.br

\section{Europe}

A Guide to the use of Terms in Plant Pathology

http://www.bspp.org.uk/fbpp.htm 
Table 2. Continuation...

\author{
Cereal Pathology at Scottish Crop Research Institute (SCRI), \\ UK \\ http://www.scri.sari.ac.uk/mbn/cerpath/cerpath.htm \\ Chemical Ecology (Sweden) \\ http://www.vsv.slu.se/cec/h.htm \\ ExPASy - Molecular Biology Server (Switzerland) \\ http://www.expasy.ch/ \\ IPM Europe (UK) \\ http://www.nri.org/IPMEurope/homepage.htm \\ The Pherolist (Sweden) \\ http://www-pherolist.slu.se/

\section{International} \\ FAO: Pesticide Management \\ http://www.fao.org/waicent/FaoInfo/Agricult/AGP/AGPP/ \\ Pesticid/ \\ Global Plant Protection Information System \\ http://pppis.fao.org/ \\ IMPnet \\ http://www.IPMnet.org/ \\ International Survey of Herbicide-Resistant Weeds \\ http://www.weedscience.com/ \\ The Universal Virus Database \\ http://life.anu.edu.au/viruses/canintro1.htm

\section{Industry} \\ American Crop Protection Association's IPM: The Quiet
}

Evolution

http://www.acpa.org/public/pubs/quiteevol.html

Cyanamid's Weed Identification Guide

http:/www.cyanamid.com/tools/weedguide/index.shtml

Integrated Pest Management (IPM) from Asia-PacificCrop

Protection Association

http://www.apcpa.org/ipm.htm

\section{Growers}

Grape Grower's Notebook

http://users.erols.com/gmead/

North American Fruit Explorers Website

http://www.nafex.org/

\section{Books/Literature}

AGRICOLA- The bibliographic database

http://www.nal.usda.gov/ag98/

Florida Entomologist (Online Journal, USA)

http://www.fcla.edu/FlaEnt/

Quantitative Population Ecology (A. Sharov,

Dept. of Entomology, Virginia Tech, USA.)

http://www.gypsymoth.ento.vt.edu/ sharov/PopEcol/

popecol.html

Radcliffe's IPM World Textbook

http://ipmworld.umn.edu/

Texas Plant Disease Handbook (USA)

http://cygnus.tamu.edu/Texlab/tpdh.html are maintained by an Email Server (software) that automatically distributes an email message from one member of a list to all other members on that list. Several IPM lists in the form of digests, electronic journals, discussion groups and the like are now available. Liszt $<$ http://www.liszt.com $>$ and Meta-List.net $<$ http:// www.meta-list.net $>$ can be used to search for a specialty mailing list.

Internet Relay Chat (IRC) is a real-time, text-based, communication program that allows groups of users to talk to one another. Unlike News Groups, IRC does not create a record or log of what is discussed. IRC is best used to get immediate feedback from many users. Instant Messaging (IM) is an emerging method for two or more users to share information in real time. Neither chat nor IM have been fully exploited for IPM to date.

\section{The Internet and Decision Support Systems}

The web provides an excellent interface for all kinds of interactive networking. This aspect allows the web to be used as a network "front-end" for many kinds of analyses and data processing. Web-based models and Decision Support Systems (DSS) are becoming popular because little or no client software is required, thus reducing software management and distribution costs (Power \& Kaparthi 1998). Several internet-based DSS have been developed for industry, medicine, business, meteorology, and agriculture. DSS have emerged as essential tools to bridge the gap between science-based technology and end-users who make day-to-day management decisions. A DSS integrates a user-friendly front end to often complex models, knowledgebases, expert systems, and database technologies (Coulson et al. 1987, Jones 1989). A general DSS web site is "DSS Resources" <http://www.dssresources.com> (Power 2000). This site provides information on basic concepts, development, deployment, and evaluation of DSS's. Also, it links to university and research DSS sites and case studies, various web-based DSS's and DSS related articles, web sites of DSS companies, etc.

Static, dynamic and interactive IPM resources can be integrated into a centralized decision support system (DSS). The scope of this system can be regional, multi-regional, national, or international. As a rule, an IPM - DSS should provide users all necessary information including pest identification/disease diagnosis, pest/pathogen life histories (cycles), sampling and decision making criteria, sampling program and economic injury level calculators, pest/disease developmental models linked to weather networks, biorational pest control methods, plus currently available pesticides, and their safety issues and environmental impacts.

There are no true IPM DSSs' online at this time, but many of resources are available and waiting for proper integration. Examples of incipient interactive IPM systems include the Oregon Pest Alert System (ORPAS) (http:// ippc.orst.edu/pestalert/) (Bajwa 2002). ORPAS is the first, fully-functioned, near-real time pest warning and reporting 
system. Based on integrating e-mail, websites, and databases, ORPAS provides an electronic means for sharing immediate pest outbreak alerts, forecasts, and other timely information between growers, field personnel, extensionists, and researchers. The system encourages precise and judicious action and is expected to improve pest management decision-making by stakeholders. Events to be reported include pest development status and buildup, levels of biocontrol agents, and other pest-related occurrences. The system offers the advantage of immediacy and information sharing between various stakeholders. The regional and multi-regional scale deployment of these interactive, integrated tools encourages development of areawide integrated pest management programs, and promotes a landscape-scale perspective for all stakeholders.

Various weather-based disease and insect pest models are available online for local forecasting of pest situations based on real time, near-real time, and/or historical weather data. For example, the phenology model database of the University of California Statewide IPM Project (UCIPM 2002) contains information about, and models of, more than 100 plants, pests, and beneficial organisms (predators and parasitoids). This information can be utilized for developing web-based pest management DSS. The Integrated Plant Protection Center (IPPC) $<$ http://ippc.orst.edu $>$ of Oregon State University developed several online interactive resources including near real-time daily weather data, various degree-day products (calculators, phenology models, maps, and map calculator), and weather-based phenology models for pest management decision-making in the four Northwestern U.S. states (Oregon, Washington, Idaho, and Montana) (Coop et al. 2001). Forecasting pest and disease incidence and development is highly valuable in planning and adjusting control measures.

Another example is the Codling Moth Information Support System (CMISS) <http://ippc.orst.edu/codlingmoth $>$ (Bajwa \& Kogan 2001). This site contains various knowledgebases, databases, phenology models, and links to worldwide resources on codling moth. Currently, there is an evolution of pest control recommendation resources towards online interactive, more comprehensive decision support tools. Examples include Cornell University vegetable IPM recommendations at $<$ http://www.nysaes.cornell.edu/ recommends $>$ and Pacific Northwest Plant disease control guidelines at $<\mathrm{http}: / /$ plant-disease.orst.edu $>$.

\section{The Internet and Global Collaboration on Information Development and Use}

The web facilitates the potential for global collaboration on information development and use. Such a collaboration reduces redundant efforts and costs, and can result in products that are better than those produced by autonomous efforts (Gilman \& Green 1998). The Internet is impacting cooperative research on a global scale (King et al. 1998). Several international, public-domain databases are now online and are available free of charge. Among these are several molecular biology and bibliographic databases such as Genbank and Agricola. GenBank is the U.S. National Institute of Health (NIH) genetic sequence database, an annotated collection of all publicly available DNA sequences. GenBank is part of the International Nucleotide Sequence Database Collaboration, which is comprised of the DNA DataBank of Japan (DDBJ), the European Molecular Biology Laboratory (EMBL), and the US National Center for Biotechnology Information (NCBI). These three organizations exchange data on a daily basis. The GenBank database and related resources are freely accessible at: <http://www.ncbi.nlm.nih.gov>. AGRICOLA (AGRICultural OnLine Access) is a database of bibliographic records created by the U.S. National Agricultural Library and its cooperators. This database covers materials dating from the 16th century to the present. The records describe publications and resources encompassing all aspects of agriculture and allied disciplines. AGRICOLA can be searched via the web at http://www.nal.usda.gov/ag98/.

\section{The Internet and Extension Services}

The transfer of research and extension information to farmers plays the key role in the adoption of IPM. Electronic communication provides an effective multidirectional exchange of information. A continuum of communication and information exchange technologies and modes commonly used in extension and education programs is given in Fig. 2. Electronic extension systems provide $24 \mathrm{~h}$ access to an inquirer of specific information to be used in planning and decision support. In fact, it is rapidly changing the way individuals exchange information and make decisions. Now it is possible for extension services and applied researchers to deliver and receive information to and from much larger audiences via fax (both Internet- and telephone-based document delivery systems), multimedia programs, email, and the web. The emphasis is, however, beginning to shift from traditional one-way flow of information from research, then to extension, and finally to end-users of information, to the more egalitarian process where the pool of total experience and knowledge available in the community, from growers, industry, research and extension, is readily exchanged through electronic means, focused learning workshops, and increased on-farm applied research.

The impact of modern electronic technology for extension information communication has been anticipated over a decade ago (Dik \& Travieso 1986), however no one may have predicted the opportunities that have been opened with advent of the Internet and the Web. An Internet-based network provides one virtual platform for a decentralized organization like the cooperative extension service with its dispersed personnel and operation, by bridging the distance gap and operating as a unit. According to Trede \& Miller (1993), there are a few barriers such as lack of time on the part of extension personnel, funds, training, and experience to efficiently using this technology for information delivery and analysis. Nevertheless, email and other Internet tools are widely used and preferred by extension agents for exchanging time-sensitive information and networking with researchers and subject specialists. Extension agents view the web as an information resource with great potential for just-in-time communications. 


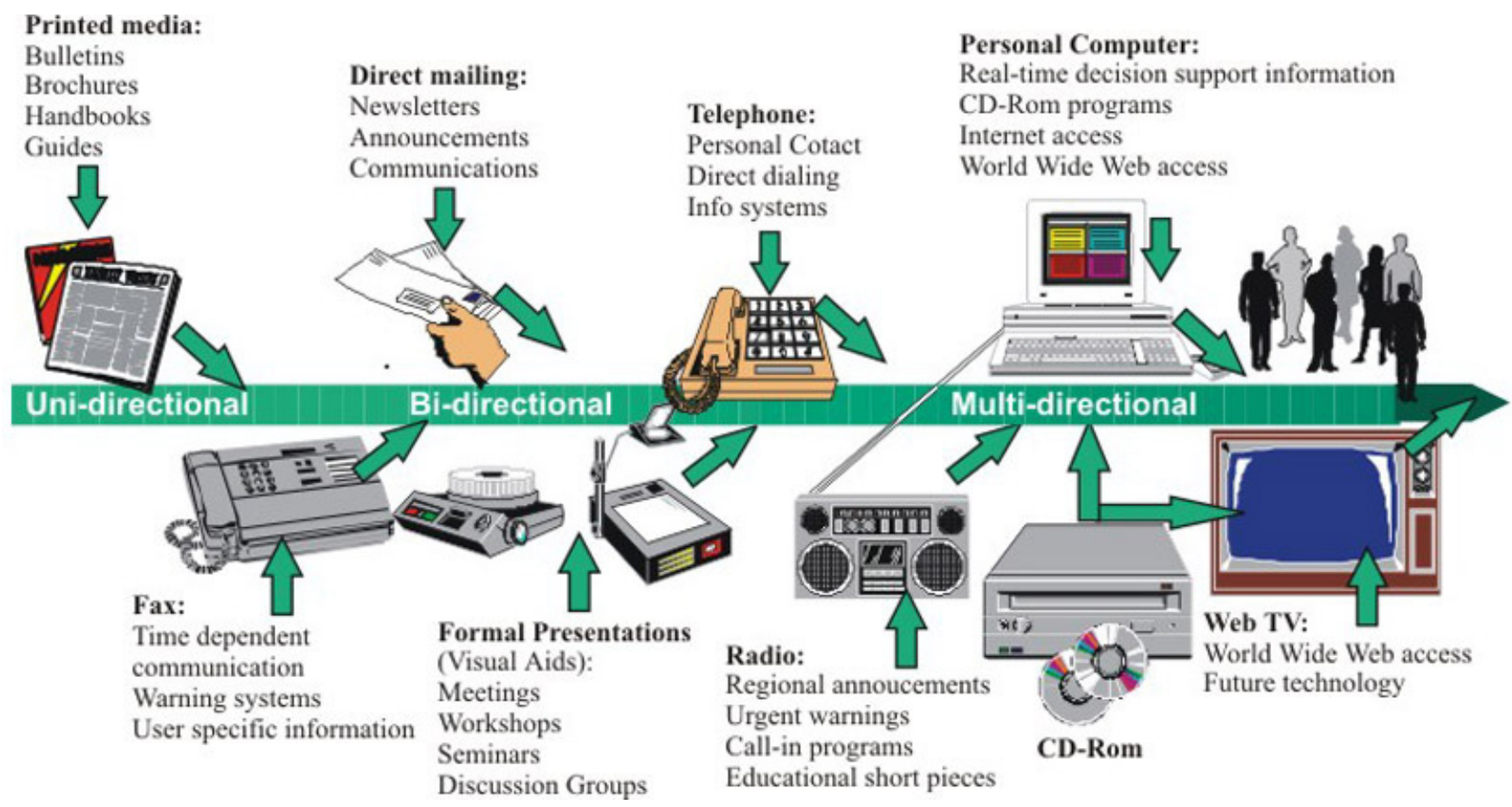

Figure 2. Continuum of communication and information exchange technologies and nodes commonly used in extension and education programs.

Information exchange by electronic means has revitalized the role of extension services in providing information, education, and decision making assistance to agricultural producers. Cooperative extension services in many countries have developed electronic information systems. For example, the states of Florida $<$ http://edis.ifas.ufl.edu/ $>$ and Colorado $<$ http://www.colostate.edu/Depts/CoopExt/index.html $>$ (USA) offer the majority of their publications through the web or on CD-ROM. Now, it is possible to use an electronic mail or "Ask an Expert" (AAE) web page for requesting information from extension professionals on a specific topic. The Web-based systems rely on email servers/clients for responding to the queries; however, a record of each question and its answer is kept in a searchable database. Clients have access to these services $24 \mathrm{~h}$ a day to identify and contact an expert for answering questions. With these systems, extension professionals may respond in a more thoughtful manner by completing research. These systems are better than using a telephone to call a professional who may not have information readily available thus requiring additional phone calls and time delays. Many extension services offer searchable AAE databases. Examples include "Ask an Expert" $<$ http:// www 1.agric.gov.ab.ca/staff/ate.nsf $>$ of Alberta Agriculture, Food and Rural Development (Canada), and "Ask Our Experts!" $\quad<$ http://www.ppdl.purdue.edu/ppdl/ Ask_Expert.html $>$ of Virtual Plant \& Pest Diagnostic Laboratory, Purdue University (USA).

A digital photograph of a plant problem can be sent to a crop consultant for proper advising and treatment recommendations. These services are readily accepted and greatly appreciated by the public (Gilman \& Green 1998). It seems that using electronic means of information exchange enhances the image of the extension services as a modern and effective source of information, education, and decision support for its clientele, thus strengthening its leadership role. One example is the Distance Diagnostic Identification System (DDIS) (http://edis.ifas.ufl.edu/MENU_DDIS) from the University of Florida, USA.

Web-based information systems and databases are now becoming essential information delivery /exchange tools for the Cooperative Extension Service. These resources are freely accessible by users, whether a producer, a professional consultant, or an extension worker. These systems provide a solid base for exchanging information between experts and their clientele. They have proved to be efficient and costeffective means of decision-support in agriculture. Online databases (e.g., for decision support in IPM) increase the ability of an extension professional to provide the latest information to the local public. In addition, they enable extension professionals to keep in touch with the technological advancements in areas inside and outside their personal expertise. Also, research and information needs may be identified by gaps in databases.

The scope of web-based information delivery is not just limited to a particular (local) area/community. It is readily available to broader areas resulting in less duplication of effort by local experts. If appropriately coordinated, it can significantly improve collaborative efforts among professionals in the neighboring areas/states/ countries, thus greatly enhancing the quality of information (Bajwa \& Kogan 2003). With the Internet, specialists can participate cooperatively in a wide-area/national project with minimum travel and other expense involved. Electronic networking may ease and enhance extension 
specialists-researchers interactivity and cooperative development of comprehensive national and international databases. It may reduce overhead costs such as telephone, mail, printing, and storage costs.

A wealth of online, extension IPM resources exists including identification keys, diagnostic guides, predictive models, in-season pest alerts, pest and disease management guidelines, pest management alternatives, etc. Examples of some outstanding resources are given in Table 2.

\section{The Internet and Education}

The web provides an exciting new opportunity for distance teaching and learning. Internet tools such as email and the web are widely used in universities and other educational institutions. Virtual online seminars and text-based lectures are delivered daily. Entire courses and degrees are offered with students never having to visit the physical campus. Students can participate in case studies and debates from remote locations across the Internet. Educators offer electronic office hours and host discussion groups to assist students in ways that expand the time when students can reach out for help. The Internet has also become a very powerful information providing system for dissemination of educational materials.

The Internet has a huge potential for improving effectiveness and efficiency for all educational institutions. Its ability to allow access to information and knowledge across the world, enhances communication between colleagues, and provides a new teaching medium for student centered learning can assist educators in several ways. If adoption by the educational community is successful, educators will have access to curriculum materials, content area information, current events, state and local happenings, and be able to keep in touch with colleagues across the globe from a computer on their desktop.

\section{The Internet and Research}

Internet tools like email and the Web are frequently used in the academic/scientific communities. Research activities like literature search and acquisition, and research collaboration are the most impacted by the Internet. However, other uses are emerging. Most informational databases, previously available in the academic libraries or university's Local Area Networks (LAN), are now online. The same is true for most journals and magazines. Some online databases provide information directly, but most are bibliographic, providing only references to the literature where information can be found; abstracts are sometimes given as an option. However, online searching has recently been undergoing a shift in focus, with full-text databases appearing. These databases offer access to primary sources through the complete text of articles and books, bypassing the bibliographic stage.

Majority of online resources are free except for the most recent issues of journals/serials and commercial database services. Corporate subscriptions to these services and resources (online journals and other serials) permit employees/students/users to read, download or print the whole article using their own computer. Several publishers have already made, or are in a process of making, issues published more than four years ago available free of charge. The Internet is also being used by researchers in data collection, analysis, and as a tool for publishing scholarly journals (Oblinger \& Maruyama 1996). Electronic surveys (both web- and email-based) have proved to be cost effective and a convenient method of collecting data for extension and agricultural specialists. Surveys based on email did not adversely affect the return rate or response, effectively yielding the same results as a paper survey (Bajwa \& Kogan 2003). WWW provides a cost-effective conduit to disseminate research-based information. Research results can be published on the web rapidly.

Several online databases provide up-to-date information on a given topic. They can be used to identify research and information needs by exploring the gaps in knowledge. Graduate students may use these resources to find new thesis topics. A few examples of these resources include genome databases for several plant, fungal, and other organisms available at: http://ars-genome.cornell.edu. The site is a user friendly system with a variety of information on cotton, maize, wheat, barley, rye, beans (Glycine, Phaseolus, Vigna), pearl millet, rice, solanaceae, rosaceae, rice blast fungus (Magnaporthe grisea), and fungal pathogens of small-grain cereals. This site also hosts various botanical databases on plant ecological ranges, native American food plants, medicinal plants of native America, phytochemicals, plant variety protection, and worldwide plant uses. The site is very useful for finding information on a plant species and its associated organisms such as arthropod fauna and microbial flora. Another resource, NEMABASE <http:// ucdnema.ucdavis.edu/imagemap/nemmap/nemabase.htm> is a database on the host status of plant species for plantparasitic nematodes. This database contains information (for each host-parasite interaction) on nematode species, nematode subspecific designation, host species and cultivar, susceptibility to damage, damage functions and thresholds, geographic location, and fungal, bacterial or viral interactions. The "Ecological Database of the World's Insect Pathogens (EDWIP)" < http://insectweb.inhs.uiuc.edu/ pathogens/EDWIP/> provides information on fungi, viruses protozoa, mollicutes, nematodes, and bacteria (other than Bacillus thuringiensis) infectious to insects, mites, and other arthropods. This source provides information on host range, countries, and habitats where host-pathogen association can be observed. This database can be used for risk analysis and environmental impact assessment of the use of entomopathogens as control agents for insect and mite pests. Plant Viruses Online <http://biology.anu.edu.au/Groups/ $\mathrm{MES} / \mathrm{vide} / \mathrm{refs} . \mathrm{htm}>$ contains information on most species of virus known to infect plants including viruses with virions and those (e.g. umbraviruses) that have no virion protein genes of their own, and use the virion proteins of their symbiotic helper viruses instead. Resources such as International Survey of Herbicide-Resistant Weeds $<$ http:/ /www.weedscience.com $>$, and Insecticide Resistance Action Committee (IRAC) <http://PlantProtection.org/IRAC>, 
contain general and specific information about respective pesticide insecticide resistance, latest facts, and results of worldwide surveys.

\section{The Retrieval of Internet-Based IPM Information}

IPM is an information-intensive system for the control of pest populations whenever they impinge on human activity and well being (or welfare). Its research and implementation depend on the reliable supply of timely information. IPM researchers, like other scientists, must rely on access to data from extant studies. The Internet (particularly the web) has opened a vast array of data resources for IPM research, extension, teaching, and learning that was not readily available before. The web is fast becoming a critical component of IPM information exchange. Search tools on the Web, called search engines and directories, which index Internet sites, offer keyword searching and subject browsing of information. There are now thousands of IPM sites online from all over the world.The future of IPM delivery systems through the Internet is promising; internet-based information exchange is quickly becoming an absolute requirement for local, regional/areawide, and international implementation of IPM systems.

The Internet is a repository of all kinds of information. In fact, the amount of this information has overwhelmed its current information management and search technology. Commonly used search agents (e.g., Googles, Yahoo, HotBot, Alta Vista, Excite, Northern Light, Magellan, etc.) index only one-third of the total web pages which are expected to grow exponentially over the next few years. General search engines are typically of two types: evaluative or non-evaluative. Evaluative search engines include sites evaluated for quality by a person (generally a database manager, not a subject specialist). Generally, these search tools return fewer "hits" as their databases are usually smaller because of the time necessary for evaluation. An example of an evaluative search engine is Magellan. It includes a summary, a link to the review, and a link to the site itself for each document retrieved. Nonevaluative search engines usually rely on automation. Now, search engines increasingly include a hierarchical directory structure for categorizing their web pages. Advanced search features are often available from most general search engines. These features includes Boolean searching, duplication detection, limiting retrieval by field.

It is a challenge to find required information on a specific topic. Using common search engine sites, at times of peak traffic, may be overloaded and attempts to connect may be refused. A good strategy is, however, to narrow the search by their advanced utilities using logical operators AND, OR, NEAR and NOT. Subject guides/ directories and specialty search engines are preferred because they are more specific and quite easy to use. Subject guides can be used as a reference point for information retrieval on a given topic.

Examples of some of the best IPM related guides are Plant Pathology Internet Guide Book (PPIGB) <http:// www.ifgb.uni-hannover.de/extern/ppigb/ppigb.htm>, Entomology Index of Internet Resources <http:// www.ent.iastate.edu/list/>, and Insects WWW $<$ http:// www.isis.vt.edu/ fanjun/text/Links.html $>$. Specialty Search Engines are subject specific searching utilities; among them is DIR < http://IPMnet.org/DIR/; ippc.orst.edu/DIR), which is like the "Google" of online IPM information. Infomine (a scholarly resource guide for biological, agricultural, and medical sciences) of the University of California designates DIR as "a well organized, annotated web virtual library of IPM information". (Infomine is available at: http:// infomine.ucr.edu/search/bioagsearch.phtml. Several other examples of specialty search engines are available from the IPM Informatics web site (http://ippc.orst.edu/ ipminformatics/) (Bajwa \& Kogan 1997).

\section{Conclusions}

We have summarized many of the new Internet technologies available today, along with some examples relevant to IPM. The Internet's potential will be, like the concept of a decision support system, an integrative system of static, dynamic, and real-time multi-way communications and information. There are, however, no real examples that represent this potential at present. There are several constraints to IPM's adoption of the Internet. Since the Internet and especially the web are relatively new technologies, their adoption and potential for changing the business of IPM are in the earliest stages. There is yet a "founders effect" or "chicken and egg" problem, where end-users are slow to adopt because of lack of applications, while professionals will not yet commit to building such applications due to a perceived lack of users. In fact, few research or extension personnel even share the same vision of what the internet can offer, and for those with new ideas, the technologies are changing so fast that we must constantly check our ideas against the technologies available.

The effort involved in hearing about, comprehending, evaluating, planning and developing, pilot-testing, and implementing new internet technologies is beyond the time available or technical skill level of most workers trained in more traditional IPM tasks. The examples to date often represent extraordinary effort and creativity in exploiting this new medium, even when institutional administration and support mechanisms hardly recognize such initiatives as professional activities. With time, internet-hosted activities will achieve equal recognition and acceptance as other scholarly pursuits. Another problem alluded to earlier is the complexity of any internet effort beyond the simplest websites that contain only text and graphics. Dynamic content such as required by decision support systems is not simple or easy to develop, and standards have not yet matured in most cases.

The integration of various internet protocols has not yet occurred. Such integration, however, is highly desirable for most IPM decision making activities that depend upon information gathering, such as on pest identification, biologies and management options, use of dynamic inputs such as 
weather data and current field conditions for forecast models, environmental data such as the side effects expected for a given management option, and so on. While some good examples highlight the potential of individual protocols which the internet now supports, their integration remains an unsolved problem at this time. But other existing non-internet technologies such as printed materials, fax, and voice telecommunications and GPS do complement the internet and will remain vital to IPM decision making. It is promising, however, that after only about eight years since the internet was first used for agriculture, that so many excellent resources are available, and that improvement and further adoption are seen on a daily basis during new era of the internet's exponential growth.

\section{Acknowledgments}

This paper originated from a workshop conducted at the National Soybean Research Center of Embrapa in June 2003, sponsored by Embrapa-Labex-USA. The authors are particularly thankful to Dr. Antônio R. Panizzi for his continuous encouragement to write this paper and for his efforts for arranging the workshop.

\section{Literature Cited}

Bajwa, W. 2002. Oregon pest alert system (http:// ippc.orst.edu/pestalert/).

Bajwa, W.I. \& M. Kogan. 1997. [On-line]. IPM informatics. Electronic knowledgebase. Oregon State University $<\mathrm{http}$ ://ippc.orst.edu/ipminformatics $>$.

Bajwa, W.I. \& M. Kogan. 2000a. Database management system for Internet IPM information, p. 216-220. In M. Shenk, M. Kogan \& A. Deutsch (eds.), IPM in Oregon: Achievements and future directions. Oregon State University, Corvallis, Oregon, 227p.

Bajwa, W.I. \& M. Kogan. 2000b. An interactive knowledgebased system for integrated codling moth management, p. 211-226. In M. Shenk \& M. Kogan (eds.), IPM in Oregon: Achievements and future directions. Oregon State University, Corvallis, Oregon, 227p.

Bajwa, W. \& M. Kogan. 2003. Online resources for IPM information delivery and exchange. In Integrated pest management in the global arena, CABI (UK), in press.

Coop, L. 2002. IPM weather data and degree-days (http:// www.orst.edu/Dept/IPPC/wea/).

Coop, L., M. Kogan \& W. Bajwa. 2001. Information exchange driven IPM: applied research and decision support. Oregon State Univ. Integrated Plant Protection Center web site: http://osu.orst.edu/Dept/IPPC/wea/ Rpt_WR_IPM_01c.html.
Coulson, R.N., L.J. Folse \& D.K. Loh. 1987. Artificial intelligence and natural resource manahement. Science 237: $262-267$.

Dik, D.W. \& C.B. Travieso. 1986. Future role of electronic technology in agricultural research and extension. The yearbook of agriculture, p. 272-281.USDA, Washington, D.C., 330p.

Eastwood, B.R. 1998. Agricultural databases for decision support. HortTechnology 8: 320-324.

Gardner, E. 1999. Net is advancing quickly toward massmedia status in United States. Internet World 5: 13-14.

Gilman, E. F. \& J. L. Green. 1998. Efficient, collaborative, inquiry-driven electronic information systems. HortTechnology 8: 297-300.

Green, D.G. \& N. I. Klomp. 1998. Environmental informatics - a new paradigm for coping with complexity in nature. Complexity International Vol. $6<\mathrm{http}$ // www.csu.edu.au/ci/vol06/green/green.html>.

Jones, J.W. 1989. Integrating models with expert systems and data bases for decision making, p.194-211. In Climate \& agriculture - system approaches to decision making, A. Weiss, Ed. Charleston Sc 5-7 March 1989, 256p.

King, R.P., S.M. Swinton, D. W. Lybecker \& C. A. Oriade. 1998. The economics of weed control and the value of weed management information. p. 25 - 41. In J.L Hatfield, D.D. Buhler \& B.A. Stewart (eds.). Integrated weed and soil management. Ann Arbor Press, Chelsea, Michigan, 385 p.

Kogan, M \& W. I. Bajwa. 1999. Integrated pest management: a global reality. An. Soc. Entomol. Brasil 28: $1-25$.

Lineberger, R. D. 1998. Integrating the World Wide Web into existing extension and educational technology. HortTechnology 8: 313-315.

Miller, S.E. 1993. The information age and agricultural entomology. Bull. Entomol. Res. 83: 471-474.

NUA Surveys 2002. Nua Internet survey (http//http:// www.nua.ie/>.

Oblinger, D. G. \& M.K. Maruyama. 1996. Distributed learning. CAUSE Professional Paper Series, No. 14. New York, 39p.

Power, D.J. 2000. Decision support systems Web Tour. World Wide Web, http://dssresources.com/tour, version 3.1, February 4, 2000.

Power, D. J. \& S. Kaparthi. 1998. The changing 
technological context of decision support systems, p. 4154. In D. Berkeley, G. Widmeyer, P. Brezillion \& V. Rajkovic (eds.), Context-sensitive decision support systems. London, Chapman and Hall, 215p.

Strassmann, P.A. 2000. Knowledge metrics. Knowledge Manage. 3:16.

Thysen, I. 1998. First Asian conference for information technology in agriculture Wakayama-City, Japan
January 24-26, 1998. [Online]. Trends in information technology in agriculture (http://www.sp.dk/ iver/ afita98/it-trend.htm).

Trede, L.D. \& Miller, W.W. 1993. Educational technology tools used by extension professionals in the North Central Region. J. Agric. Educ.: 34.

UCIPM. 2002. UC IPM onlie (electronic Publication). (http:/ /axp.ipm.ucdavis.edu). 